\title{
O uso de Dioniso como item de propaganda na revolta de Espártaco: um estudo de caso
}

Vicente Dobroruka ${ }^{1 *}$

${ }^{1}$ Universidade de Brasília, Brasília/DF - Brasil

\section{RESUMO}

Neste artigo ${ }^{1}$ procura-se estabelecer a relação entre o quadro mais geral das Guerras Servis na Itália (notadamente a Terceira, ou Revolta de Espártaco, ocorrida entre 73-71 AEC) e os episódios de êxtase dionisíaco em diferentes momentos e locais relacionados a Espártaco. Atenção especial é dada aos aspectos trácios que ligam as serpentes (animal sagrado no culto ao deus, ou a seus assemelhados na Índia) à propaganda pró-Espártaco - em geral, ligada à companheira de Espártaco. As serpentes tomam um espaço especial nessa discussão pela frequência com que sáo mencionadas e pela certeza com que se pode relacioná-las ao culto de Dioniso, popular entre os escravos italianos durante e após a revolta.

Palavras-chave: sincretismo religioso na Antiguidade; resistência cultural no mundo antigo; Guerras Servis; historiografia antiga.

\section{Dionysus as sacred propaganda in the Spartacus' Revolt: a case-study}

\section{ABSTRACT}

In this article we discuss the relationship between the general picture of the Servile Wars in Italy (with special regard to the Third one, more commonly known as The Spartacus' War, between 73-71 BCE) and episodes of Dionisiac ecstasies in different moments and places related to the revolt. The snake is a particularly important animal in this scenery given their popularity in Dionisiac cults or their equivalents in, e.g., India. The use of snakesDionisus as propaganda for the rebellion is in great measure attributed to Spartacus' female companion, herself a keen Dionisiac devotee.

DOI: http://dx.doi.org/10.1590/2237-101X02104401

Artigo recebido em 30 de maio de 2019 e aceito para publicação em 17 de setembro de 2019.

* Professor da Universidade de Brasília / Departamento de História, Brasília/DF - Brasil. E-mail: vicente. dobroruka@gmail.com. ORCID: https://orcid.org/0000-0002-0151-6119.

${ }^{1}$ Uma breve nota de agradecimento faz-se necessária: sem a ajuda de Eliz Soares (UMESP) e de minha assistente de pesquisa Isabela Ramos, este artigo seria inviável, quer pela dificuldade em localizar bibliografia, quer pela ausência de críticas ao longo do caminho. 
Keywords: religious syncreticism in Antiquity; cultural resistance in the Ancient World; Servile Wars; ancient historiography.

\section{El uso de Dionisio como ítem de propaganda en la revuelta de Espartaco: un estudio de caso}

\section{RESUMEN}

En este artículo se busca establecer la relación entre el cuadro más general de las Guerras Serviles (especialmente la Tercera, o Revuelta de Espartaco, ocurrida entre 73-71 a. C.) y los episodios de éxtasis dionisíaco en diferentes momentos y locales relacionados a Espartaco. Es dada una atención particular a los aspectos traídos que relacionan las serpientes (animal sagrado en el culto al dios, o a sus semejantes en la India) a la propaganda pro Espartaco en general, vinculada a la compañera de Espartaco. Las serpientes toman un espacio representativo en esta discusión por la frecuencia con que son mencionadas y por la certeza con que se puede relacionarlas al culto de Dionisio, popular entre los esclavos italianos durante y después de la revuelta.

Palabras clave: sincretismo religioso en la Antigüedad; resistencia cultural en el mundo antiguo; Guerras Serviles; historiografía antigua.

Non habemus illos hostes, sed facimus.

Sêneca, Epistolas

\section{O problema religioso nas revoltas servis: um quadro geral}

Este artigo é o primeiro de uma série organizada temática, mas não cronologicamente. Trata dos aspectos de história social, cultural ou, se preferirmos, do uso de temas religiosos a serviço de lutas sociais, legitimação de governantes ou incitação a rebelióes no Mediterrâneo helenístico-romano, entre os séculos III AEC - IV EC. Começo por Espártaco por ele ser, provavelmente, o rebelde que mais cativou a imaginação dos homens, historiadores ou não, em todos os tempos; nenhum rebelde é tão popular nem forneceu inspiração para tantos movimentos no futuro.

Muito sucintamente, os dados essenciais da rebelião serão sumarizados aqui e podem ser encontrados, sem divergência factual, em qualquer manual de História Antiga ou, para o leitor mais interessado, nas fontes primárias ${ }^{2}$. Espártaco devia estar na casa dos trinta e pou-

\footnotetext{
${ }^{2}$ Para as fontes primárias foram utilizadas, a menos que especificado, as edições da Loeb Classical Library
} 
cos anos quando se rebelou em Cápua, no ludus ${ }^{3}$ de Lentulus Vatia (Batiatus e termos derivados estão provavelmente errados, embora popularizados pela mídia). Não sabemos o que ocasionou a rebelião; o estatuto de um gladiador no mundo romano era bem mais ambíguo do que o de outros escravos ${ }^{4}$. Espártaco deve ter sido um homem de inteligência incomum e possivelmente serviu como auxiliarius $^{5}$ de alguma unidade maior romana (ironicamente, se isso ocorreu, deve ter sido sob as tropas de Sulla na década de $80 \mathrm{AEC}^{6}$ ).

Como Espártaco tornou-se escravo é dado ignorado, embora Apiano afirme que isso ocorreu logo após ter servido junto aos romanos ; todavia, sua rebelião insere-se numa sequência longa, que vai de meados do séc. III AEC até o Império juridicamente constituído como tal - estamos falando da longa duração, de um período de pelo menos 500 anos de rebelióes estourando por todos os cantos do mundo romano tendo, quase sempre, motivação ou amparo no fenômeno religioso. A grande exceção parece a traição de Arminius, que culminou no (erroneamente) denominado "Massacre da Floresta Negra”, 9 EC. Os demais tiveram invariavelmente um componente religioso e amiúde soteriológico - as revoltas de

em seu formato online em www.loebclassics.com. Para os poucos fragmentos de autores gregos, foi utilizada a edição de Felix Jacoby. Die Fragmente der griechischen Historiker. Leiden: Brill, 2004 (CD-ROM ed.). Para a obra de Felix Jacoby será utilizada a abreviatura FGrHist. As referências da Loeb estão indicadas após a citação dos trechos das obras antigas analisadas segundo a abreviatura $\mathbf{L C L}$, e as ediçôes dos autores antigos utilizados da Loeb se encontram listadas nas Referências. As traduçóes são do autor deste artigo, a menos que especificado em contrário.

${ }^{3}$ Ludus é um desses termos polissêmicos - significa o jogo ou combate em si, um passatempo (não necessariamente gladiatorial), ou uma brincadeira, mas também e mais importante para este artigo, a própria instalação de treinamento. Ainda que escravos, os gladiadores de um determinado ludus assemelhavam-se, sob certos aspectos, a uma família (talvez daí a lenda segundo a qual Espártaco tivesse, em combate, poupado a vida de outro gladiador, que seria colíder da revolta, Crixus). A figura do gladiador misturava, como já se disse, elementos à primeira vista incompatíveis, como nos pugilistas modernos: admiração, desprezo, temor, desejo de vê-los em açáo, mas longe dos lares dos espectadores. De todo modo, os gladiadores do período republicano eram "terceirizados", treinados e mantidos num ludus. Júlio César chegou a ter um (fundado em 49 AEC, portanto já em sua maturidade em Guerras Civis, 1.14 - CAESAR. Civil War, 1.14. LCL 39) e Cícero, numa de suas cartas, elogia os gladiadores do ludus de um amigo - carta de Cícero a Atticus, talvez de 20 de junho de 56 AEC; as metáforas retóricas ou comentários concretos sobre lutas gladiatoriais são lugar comum na obra de Cícero. Apesar da relação ambígua dos romanos (e gregos) com seus escravos, é de se notar que o gladiador podia reter para si - e não para o ludus, muito menos para um "empresário" como Vatia - os prêmios que viesse a amealhar na arena.

${ }^{4}$ Esse é um ponto de interesse especial: ao contrário dos "homens sem esperança”, os escravos agrícolas que trabalhavam acorrentados e não podiam esperar nada, nem mesmo com sua manumissão, a irrupção da revolta em Cápua pelos maus-tratos descritos por Plutarco (cf. infra, nota 20). Um texto de especial interesse, além dos trabalhos de Keith Hopkins na área, é o artigo de Ulrike Roth, "Men without hope" (2011).

${ }^{5}$ Os termos em latim e grego estão doravante simplificados sem os sinais diacríticos da IPA para facilitar a leitura e deixar mais "limpo" um texto que não tem por objeto as línguas originais das fontes em si mesmas. ${ }^{6}$ APIANO, Guerras Civis, 1.16. [APPIAN, The Civil Wars, 1.16. In: Roman History. LCL 4]. Apiano dá o fato como certo, mas a suspeita de que tenha servido com Sula é apenas uma suspeita algo irônica. O que sabemos, por Apiano, é que Espártaco servira juntamente com os romanos antes de se tornar gladiador: "Toṽ

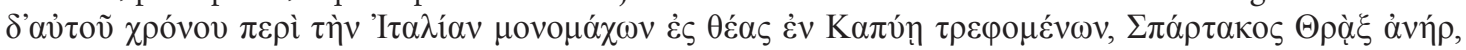

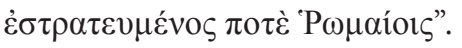

${ }^{7}$ APIANO, Guerras Civis, 1.16. [APPIAN, The Civil Wars, 1.16. In: Roman History. LCL 4]. 
escravos na Sicília em 135, em 104 AEC, a luta de Sertorius no mesmo período da revolta de Espártaco, a sublevação de Mitrídates no Oriente (as últimas três merecem um estudo de conjunto que está por ser realizado). As revoltas de escravos na Sicília, ainda que tenham sido de menor monta do que os levantes de 132 e 104, costumam ser vinculadas ao culto de Baco (Dioniso) (SHAW, 2001). Lívio mostra como o terror da desordem social, bem antes das três grandes revoltas servis da virada do séc. II para o I AEC, estava ligado ao dionisismo, ao falar de um "grande medo" que teria varrido Roma em $186 \mathrm{AEC}^{8}$.

\section{Escravidão, sociedade e medo}

Mas o medo dos escravos é um motivo comum na literatura greco-romana: Quintus Curtius Rufus, um dos principais autores de que dispomos para a vida de Alexandre, coloca na boca dos citas uma advertência que nos soaria estranha, por estar mais próxima de um conselho do que de uma ameaça: "Não creia que os seus conquistados são [seus] amigos. Não existe amizade entre senhor e escravo" .

Levando em conta a desconfiança prevalecente - e consequente vigilância - entre proprietários e escravos rurais (o cenário entre os escravos domésticos ou citadinos era inteiramente distinto, razão pela qual eram declaradamente evitados por Espártaco para comporem seu exército), a carreira de Espártaco como líder da mais conhecida revolta de escravos do mundo antigo foi curta: sua rebelião durou de 73 a 71 AEC. Sua derrota deve ter ocorrido próxima do rio Sele, local onde se tem encontrado desde 1899 restos de armas de combate romanas (aparentemente, não das armas improvisadas dos rebeldes estas podem ter se decomposto com o tempo, ou simplesmente varridas da área com vigor pelos romanos junto com os restos dos vencidos). O destino dos rebeldes é bem conhecido e unânime nas fontes antigas: dos 6 mil sobreviventes, todos foram crucificados ao longo da principal estrada romana, a Via Ápia ${ }^{10}$. Uma década depois ainda circulavam bandidos

\footnotetext{
${ }^{8}$ LÍVIO, História de Roma, 39, 2-5. [LIVY, JULIUS OBSEQUENS. History of Rome, 39, 2-5, LCL 313].

${ }^{9}$ QUINTUS C. RUFUS, História de Alexandre, 7.8.28 [QUINTUS CURTIUS. History of Alexander, 7.8.28. LCL 369]. "Quos viceris amicos tibi esse cave credas. Inter dominum et servum nulla amicitia est". Cícero teria estranhado ou ao menos qualificado o comentário, dada a preocupação que exibe com um escravo (altamente qualificado, é verdade) em suas cartas: Carta a Tiro (Leucas, 7 de novembro de 50), na qual mostra-se preocupado com a saúde do destinatário e lhe pede que não poupe esforços nem recursos no sentido de recuperá-la. É verdade que Tiro fora criado na casa de Cícero, constituindo uma relação íntima, ainda que não tão rara [CICERO. Letters to Quintus and Brutus. Letter Fragments. Letter to Octavian. LCL 462].

${ }^{10}$ Para toda a história de Espártaco, as fontes mais importantes - e divergentes em pontos cruciais, mas irei me ater aos pontos relativos ao culto de Dioniso - são Plutarco e Apiano. Quanto a fontes de menor importância em nosso contexto, temos Salústio (Histórias) [SALLUST. Fragments of the Histories. LCL 522], alguns textos de Cícero e alguns bem tardios (Claudiano, Guerra Gótica, 155 [CLAUDIAN. The Gothic War. LCL 136]; Frontino, Estratagemas, I [FRONTINUS. Stratagems, I. LCL 174]; Tito Lívio, História de Roma, XIV: Fragmentos, sumários etc. Sumários, 682-685 - LIVY, JULIUS OBSEQUENS. v. XIV: Summaries.
} 
rurais em grupos esparsos nas montanhas do sul da Itália, que foram também vencidos e crucificados.

E, no entanto, Espártaco, como um homem antigo comum, não tinha qualquer programa social de libertação geral dos escravos ${ }^{11}$. O que ele pretendia era, aparentemente, bem restrito e o que seus lugar-tenentes desejavam, ainda menos: pouco se sabe de Enomau e de Crixus, mas parecem ter sido mais mesquinhos do que Espártaco em suas aspiraçóes ${ }^{12}$.

Paradoxalmente, sabe-se bastante a respeito das conexóes religiosas do trácio Espártaco; todas dionisíacas, em todos os episódios de sua trajetória que permitem algum exame mais acurado. É um dado importante, uma vez que Dioniso é um deus oriental ${ }^{13}$, muitas vezes representado como conquistador da Índia (em função das muitas viagens que teria feito, em certas versóes do mito $^{14}$ ) e por outros visto como originário da Ásia Menor ${ }^{15}$; é ainda visto como uma variante de Shiva, divindade da Índia (DANIÉLOU, 1984). Mais do que acerca de outras divindades de culto extático, podemos afirmar muito sobre Dioniso. Não era um deus da pólis (pelo contrário, podia ser visto como estranho aos deuses da cidade ${ }^{16}$ ).

Sendo um deus do êxtase, do vinho e dos excessos - todos tinham seu lugar nas sociedades antigas, um pouco como nas modernas temos dias, feriados ou comemoraçóes em que se faz o que seria inabitual ou mesmo proibido noutros -, Dioniso reúne características

Fragments, 682-685. LCL 404). Florus, Epitome da História Romana, 2.8 [FLORUS. Epitome of Roman History. LCL 231] e Apiano, Guerras Civis, 1.120 [APPIAN, The Civil Wars, 1.120. In: Roman History. LCL 4] frisam que o corpo de Espártaco nunca foi encontrado - o que deve ter contribuído em grande medida para a popularidade de sua revolta para a posteridade.

${ }^{11} \mathrm{O}$ melhor estudo de conjunto sobre o assunto ainda é a obra centenária de Pöhlmann (1925), com reimpressão cuidadosa de 2018. Outros trabalhos que merecem ser lidos sobre o tema são o livro supracitado de Shaw (2001), o capítulo de Kippenberg (1983) (sobre o tema mais amplo da vingança da Ásia, ou do Oriente em geral contra a Grécia, presente também na revolta de Espártaco, um trácio), de Bradley (1994) e os trabalhos seminais de Finley (1980 e 1981). Um trabalho que hoje soa datado, mas que ainda contém reflexóes interessantes, é o de Hopkins (1978), especialmente a página 120.

${ }^{12}$ Para Enomau e Crixus, a informação é breve; cf. APIANO, Guerras Civis, 1.116 [APPIAN, The Civil Wars, 1.116. In: Roman History. LCL 4].

${ }^{13} \mathrm{Ou}$ ainda (e talvez com mais frequência) como um deus de origem trácia: cf. ARCHIBALD (1999).

${ }^{14}$ A mais conhecida dessas referências talvez seja a de Arriano, ainda que tardia, em sua Anábase de Alexandre, 5.5, em que Dioniso é comparado a Alexandre e a população da cidade de Nysa (situada em várias localidades, geograficamente, mas nunca localizada de fato) suplica a Alexandre que seja deixada em paz, por conta do respeito a Dioniso [ARRIAN. Anabasis of Alexander, 5.5. LCL 269].

${ }^{15}$ Em algumas versōes, Dioniso é situado entre a Fenícia e o Egito (Hino Homérico n. 1, a Dioniso - fr.), no Egito apenas (DIODORO, Biblioteca Histórica, 4.2 - DIODORUS SICULUS. Library of History, 4.2. LCL 423) ou mesmo na Etiópia (HERÓDOTO, Histórias, 2.146 - HERODOTUS. The Persian Wars, 2.146. LCL 117). Para a Ásia Menor, em especial, a região da Panfília e das montanhas fronteiriças com a Armênia, temos o mito das panteras perfumadas consagradas a Dioniso (FILÓSTRATO, Vida de Apolônio de Tyana, 2.1-2 [PHILOSTRATUS. Apollonius of Tyana, 2.1-2. LCL 16.], paralelo em FÓCIO, Biblioteca, 324a 25-b18 [PHOTIUS. The Library of Photius, 324a 25-b18, 1920]), cf. DETIENNE (1979, p. 39).

${ }^{16}$ Um exemplo claro é o Dioniso caricato de Aristófanes em As rãs [ARISTOPHANES. Frogs. LCL 180.], descendo ao Hades justamente para procurar um trágico que valesse a pena (As rãs, 270 passim.); em Eurípides, a distinção entre Dioniso e a cidade perpassa toda a tragédia de As bacantes [EURIPIDES. Bacchae. LCL 495]. 
"ideais" para ser a divindade de um líder de escravos em rebelião, mais ainda pelo fato de Espártaco ser trácio (embora Plutarco ressaltasse sua inteligência, "mais própria de um grego do que de um trácio"17. O elemento religioso através do qual, anacronicamente, muitos autores modernos viram aspiraçôes igualitárias (quatro das revoltas mais importantes entre os séculos II - I AEC tinham esse componente - a de Aristônico na Ásia Menor, por sinal com o auxílio de soldados trácios; a de Eunus em 135, a de Ateniâo em 104 e a de Espártaco em 73), era exatamente isso: uma relação especial com o sagrado, que se opunha ao "sagrado dos outros" (no caso, dos romanos).

Interessante como parece, essa ideia não é nossa nem inteiramente nova. Numa obra seminal de 1991, Versnel já aponta para o rumo "helenístico" que o culto de Dioniso tomaria, precisamente por seu caráter simultaneamente estrangeiro e incontrolável (VERSNEL, 1990) ${ }^{18}$; nem todos os cultos "estranhos" à pólis tinham como ser "amestrados" ao gosto cívico, como Cibele (VERSNEL, 1990, p. 156).

\section{Revolta e religião nas Guerras Servis}

Vimos acima que as conexóes entre um deus do êxtase - mais, um deus que provavelmente era venerado discretamente pelos escravos do sul da Itália ${ }^{19}$ - e ação social-militar eram comuns a conquistadores organizados, aos resistentes e, também aos escravos revoltosos. Essa é uma distinção importante pois, do início ao fim, percebe-se algo de "ação policial" contra os rebeldes, por mais que Crasso tenha lhe dado um tratamento militar profissional em sua repressão ${ }^{20}$.

${ }_{17}$ PlutarCO. Vida de Crasso, 8. [PLUTARCH. Lives, v. III: Pericles and Fabius Maximus. Nicias and

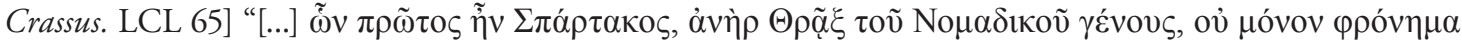

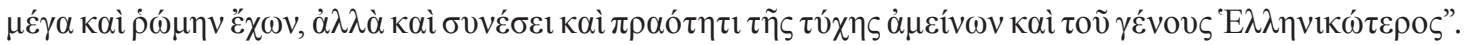
${ }^{18} \mathrm{O}$ caráter privado, por oposição à religião cívica, coloca a relação dos escravos, em geral, e de Espártaco, em particular, com Dioniso em nova perspectiva: no seu caso, mais de um elemento estranho, ou subversivo, se manifestam em sua propaganda. A mulher anônima, que foi a primeira a profetizar em seu favor (de fato, outras mulheres já eram habituées dos cultos extáticos - As bacantes são apenas um exemplo entre vários) é o elemento mais dramático: mas dada a diversidade étnica dos revoltosos, e a informação escassa de que dispomos, torna-se difícil fazer uma história do espaço sagrado na revolta de Espártaco. Um indício de que seu líder conseguiu, bem ou mal, contemporizar crenças, ritos e animais sagrados diferentes reside no simples fato de que as dissensões internas que enfrentou foram, mesmo segundo a historiografia dos vencedores, fruto de divergências operacionais e não motins contra o líder original da sublevação, Espártaco. Para mais informaçóes sobre a natureza grega e simultaneamente estrangeira de Dioniso, cf. supra notas 14, 15, 16 e 17. ${ }^{19}$ Associado, quer entre homens livres, quer entre escravos, a Zeus; EURÍPIDES, As bacantes, 121-140 [EURIPIDES. Bacchae, 121-140. LCL 495].

${ }^{20}$ Por esse motivo Crasso não teve um triunfo, reservado a comandantes romanos sob certas condiçôes; não era cabível aos romanos conceder honras militares completas a quem debelou uma rebelião de foras-da-lei. Crasso teve, entretanto, uma ovatio (a segunda celebraçáo mais importante após o triunfo), e com um pedido feito - e aceito - ao Senado: que lhe fosse permitido participar da ovatio com uma coroa de louros. PLUTARCO. Vida de Crasso, 11 [PLUTARCH. Lives, v. III: Pericles and Fabius Maximus. Nicias and Crassus, 11. LCL 65]. 
Um elemento comum a inúmeras revoltas orientais desde as invasóes de Alexandre, o Grande, é a resistência religiosa frente a governantes novos e não reconhecidos pelos nativos como legítimos, uma vez que não possuíam os requisitos de genealogia sagrados para serem monarcas das áreas conquistadas ${ }^{21}$. Mas nesse caso estamos lidando com fenômeno semelhante, mas não idêntico: o uso de divindades locais como símbolo de oposição aos "novos" deuses trazidos pelos conquistadores (EDDY, 1961, p. vii; 44; 60) ${ }^{22}$. Esse fenômeno verificou-se um pouco em toda parte - com a exceção notável da Babilônia selêucida - e fez com que cultos sincréticos surgissem (o de Serápis no Egito é um exemplo) e também que algumas ideias infelizes fossem postas em prática: a Revolta dos Macabeus, cuja natureza intestina ou antigrega não cabe discutir aqui, é um bom exemplo, com a introdução da dupla "Zeus Olímpico" = "Baal Shamayim" (ambos, literalmente, significando uma divindade superior e celestial com o Deus dos judeus. Essa assimilação era um dos limites mais duros da helenização) (VERSNEL, 1990, p. 156 ss.).

A revolta de 104 (pouco estudada) tem talvez o percurso mais bizarro: foi liderada por um certo Ateniáo (que assumiu o título do rei selêucida Diodoto Trifăo, 142-138 AEC), de quem se sabe bastante graças a Diodoro ${ }^{23}$. O elemento astrológico presente nessa rebeliáo torna ainda mais variado o cenário religioso: um erro a ser evitado é o de tratar o dionisismo trácio (logo, da companheira de Espártaco e dele próprio) e o de subestimar as demais religióes dos revoltosos. Nem todas eram extáticas e, provavelmente, a mistura de cultos, juntamente com a mistura de línguas e procedências, deve ter sido um pesadelo logístico e disciplinar para Espártaco. Mesmo que pudéssemos separar os rebeldes em quatro grandes grupos (trácios, germânicos, celtas e italianos), ainda assim teríamos aspiraçóes distintas, talvez devido às origens também distintas.

Para as fontes antigas, o motivo da rebeliáo de Espártaco parece ter sido a crueldade de Vatia, que nada tinha de religiosa; Plutarco nos diz que "a maior parte [dos gladiadores] era gaulesa ou trácia. Eles não haviam cometido nada de errado, mas, apenas por conta da

\footnotetext{
${ }^{21}$ Nesse campo, o estudo principal ainda é o de Eddy (1961). Estudos que são particularmente úteis para se entender o fluxo maciço de escravos na Península Itálica em função das guerras posteriores à Segunda Guerra Púnica são os artigos de Sanford (1937 e 1950).

${ }^{22}$ Por outro lado, Eddy (1961, p. 69; 91) adverte que não se pode falar em resistência popular generalizada em nenhuma das áreas conquistadas por Alexandre.

${ }^{23}$ DIODORO DA SICÍLIA. Biblioteca Histórica, 36, 5 [DIODORUS SICULUS. Library of History, 36,5.

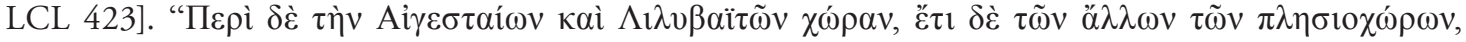

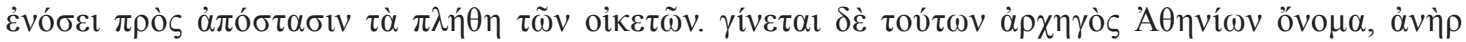

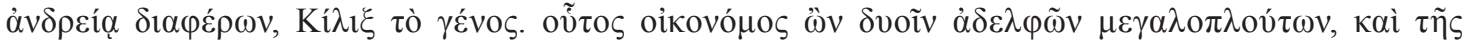

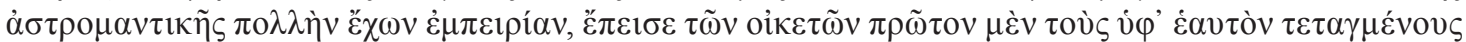

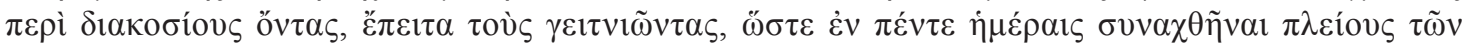
$\chi \imath \lambda i ́ \omega v "$. Nessas condiçôes é bastante interessante notar a conexão feita por Diodoro entre o rebelde Atenião e seus irmãos, ressaltando não apenas sua coragem, mas também sua habilidade como astrólogo (novamente o componente religioso como legitimador ou facilitador do recrutamento, ou inspiração para o sucesso da rebelião de 104).
} 
crueldade de seu dono, eram mantidos em condiçôes prisionais até que chegasse o momento de seu combate ${ }^{24 ”}$.

Esse é um dado que tem sido, sucessivamente, desprezado pelos historiadores de viés marxista (provavelmente devido ao apreço do próprio Marx por Apiano, uma de nossas melhores fontes para os eventos da Terceira Guerra Servil) (MARX, 2016) ou exagerado sem qualificaçôes - talvez "romantizado" seja o termo mais correto - por historiadores modernos de outras orientaçôes, mais interessados nas mentalidades, cotidiano e estruturas mentais dos revoltosos (na medida em que podem ser analisadas em conjunto - nem todos os momentos da revolta o permitem ${ }^{25}$. Provavelmente, aspectos decisivos da revolta de Espártaco teriam apelo bem restrito ao leitor ou cinéfilo atual - os êxtases de sua esposa anônima, a crucifixão de um soldado romano capturado e deixado na cruz entre seu acampamento e o de Crasso ${ }^{26}$, o massacre de tudo o que lhe dificultasse a marcha ${ }^{27}$, a morte, por suas próprias máos, de seu cavalo de batalha (fato muito significativo, dado o caráter sagrado dos cavalos entre os trácios ${ }^{28}$.

Ao fim e ao cabo, Espártaco foi um homem de seu tempo: sua vida foi curta, violenta e brutal, parafraseando Hobbes $(1651)^{29}$. Todos os envolvidos em sua perseguição, ou de seus seguidores, tiveram também morte violenta (os generais que ele derrotou logo ao início da revolta, Crasso, Pompeu, Júlio César, Catão, o Jovem e uma lista imensa da qual salva-se apenas, entre os personagens de maior importância, Marcus Lucullus, um dos generais que se aproximaram do combate cerrado a Espártaco em $71 \mathrm{AEC})^{30}$. Esse dado não é de todo absurdo, se levarmos em conta o gosto dos historiadores de todas as épocas pelo grotesco, mas, principalmente, a violência quase permanente e com limites generosos nos três últimos séculos da República.

Ainda assim, o fato de Espártaco ter sobrevivido no imaginário do homem comum é digno de nota - afinal, ele, ao contrário dos demais listados acima, era um escravo. E além

${ }^{24}$ PlutARCO, Vida de Crasso, 8 [PLUTARCH. Lives, v. III: Pericles and Fabius Maximus. Nicias and

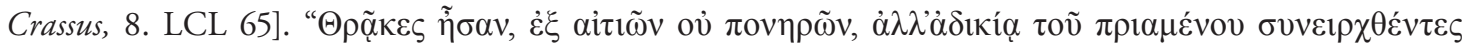

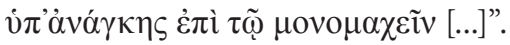

${ }^{25} \mathrm{O}$ balanço mais equilibrado é, provavelmente, "The ideology of the slaves", de Urbainczyk (2008). Shaw e Bradley figuram entre os historiadores modernos mais representativos das tendências indicadas.

${ }^{26}$ APIANO, Guerras Civis, 1.118 [APPIAN, The Civil Wars, 1.118 In: Roman History. LCL 4].

${ }^{27}$ APIANO, Guerras Civis, 1.117 [APPIAN, The Civil Wars, 1.117 In: Roman History. LCL 4].

${ }^{28}$ PLUTARCO, Vida de Crasso, 11 [PLUTARCH. Lives, v. III: Pericles and Fabius Maximus. Nicias and Crassus, 11. LCL 65]. O caráter sagrado do cavalo é atestado - ainda que escassamente, como tantos outros aspectos de sua religiosidade - em monumentos votivos ou, talvez, funerários: cf. DIMITROVA (2002).

${ }^{29}$ Em seu clássico livro em teoria política, o Leviathan: "And the life of man, solitary, poore [sic], nasty, brutish, and short" (HOBBES, 1651, p. 78).

${ }^{30}$ PLUTARCO, Vida de Lucullus, 43 [PLUTARCH. Lives, v. II: Themistocles and Camillus. Aristides and Cato Major. Cimon and Lucullus, 43. LCL 47]. É verdade que (Marcus Terentius Varro) Lucullus morreu de causas naturais e em idade avançada, mas provavelmente a morte de seu irmáo (Lucius Licinius Lucullus), logo antes da sua, deve ter contribuído para seu declínio físico. Cf. ainda APIANO, Guerras Civis, 1.92; 120 [APPIAN, The Civil Wars, 1.92; 1.120 In: Roman History. LCL 4]. 
de escravo marcado por Dioniso, um líder de revolta na qual as mulheres tiveram papel preeminente, começando por sua própria companheira anônima.

Dioniso e Espártaco: dupla de trácios, dupla profética, dupla oracular, dupla matrimonial

Convém ao historiador se perguntar sempre o "como" daquele dado fato, mentalidade ou estrutura, e, nesse sentido, o elemento religioso nas três guerras servis tem sido bem pouco estudado.

Indagando a conexão religiosa entre Espártaco e Dioniso, temos alguns dados que pouco esclarecem (por exemplo, a popularidade do culto de Dioniso na Trácia - sim, mas novamente o historiador deve se perguntar, como em Espártaco isso tornou-se um leitmotif?). Vale a pena "contabilizar" quantas vezes temos referências ao êxtase dionisíaco da mulher de Espártaco nas fontes antigas - apenas uma. Mesmo em autores muito distantes cronologicamente da revolta, inevitavelmente temos o uso de relatos anteriores; e não parece crível a "demonização" do culto de Dioniso em função de sua adoção pelo líder da revolta; o culto continuou popular entre os escravos do Sul da Itália. Outro aspecto, igualmente importante, porém distinto do último, é o do papel de Dioniso entre os revoltosos em geral. Isso pode ser inferido pela origem trácia de muitos dos revoltosos (ao menos do núcleo original de aproximadamente 70 gladiadores em fuga.

Um dado importante para os seguidores subsequentes de Espártaco é o fato de serem, em sua esmagadora maioria, escravos rurais e não urbanos: uma vez que os últimos tinham uma vida relativamente mais fácil (os escravos rurais do Sul da Itália e da Sicília eram deixados à sua própria sorte quanto aos alimentos e vestuário, contribuindo desse modo para um banditismo endêmico incentivado por seus proprietários) e por vezes exerciam funçôes altamente especializadas (médicos, secretários, contadores), tanto Espártaco não os desejava em seu "exército" como a recíproca parece ter sido verdadeira - não há registros de fugas ou adesóes em massa por parte de escravos urbanos.

Vimos acima algumas das conexóes possíveis entre Espártaco - Dioniso - Trácia. Sua origem não pode ser descartada como mero recurso retórico (por comparação com os tumultos de 186 descritos por Lívio, por exemplo). O papel das serpentes na região é notório: mesmo no caso do nascimento de Alexandre temos a vinculação ofídica-dionisíaca em diversas variantes, todas ligadas à sua mãe, Olímpia. Além de todos os contos envolvendo a mãe de Alexandre e Dioniso-serpente, poucas vezes se lembra do percurso inverso: associado a uma das formas animais de Shiva (o deus indo-europeu mais próximo de Dioniso):

Quando Alexandre conquistou partes da Índia e convulsionou outras áreas ele encontrou várias espécies de animais, entre os quais uma serpente que vivia numa caverna e era reverenciada 
pelos indianos, que lhe prestavam uma reverência grande e supersticiosa. Logo depois, eles imploraram a Alexandre para que ninguém molestasse a serpente, e ele consentiu ${ }^{31}$.

Pode-se ver aí talvez uma oposição entre campo e cidade, comum ao mundo conquistado por Alexandre; muito poucos estudiosos recentes consideram a "helenização" fenômeno uniforme e de abrangência completa em todas as regiôes conquistadas. Pelo contrário, em parte pela maior instrução e disposição da população urbana, em parte pela vocação grega para fundar cidades, a helenização trazida por Alexandre e desenvolvida por seus sucessores foi um fenômeno essencialmente urbano, embora esse dado pudesse variar conforme a região. Os populares "encantadores de serpentes" indianos podem ser um eco distante dessa tradição (JEANMAIRE, 1951, p. 403).

De todo modo, se o culto de Dioniso não era bem visto na pólis, nem na própria Roma em sua versão báquica ${ }^{32}$, ele encontraria terreno ideal entre a população escrava ou pobre da Península Itálica; a libertação extática, por breve que seja e por piores que sejam suas consequências, é melhor do que nada.

\section{A mulher anônima}

Antes de prosseguir com a análise da relação entre Dioniso, a Trácia, a serpente e Espártaco, convém verificar nas fontes de que dispomos quantas vezes a mulher aparece, e em que contextos.

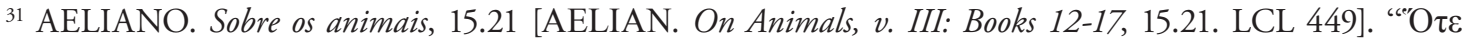

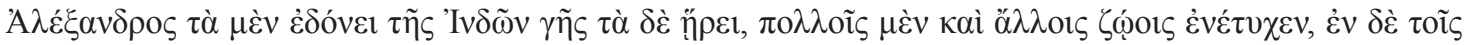

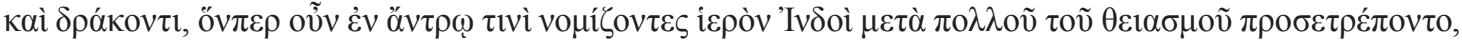

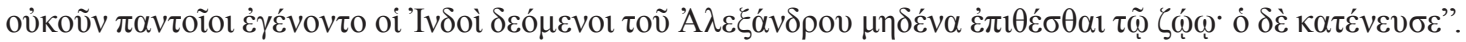
${ }^{32}$ Um exemplo manifesto disso encontra-se n'As bacantes, de Eurípides, 375-389 [EURIPIDES. Bacchae, 375389. LCL 495]; Tito Lívio reporta (talvez de modo exagerado) o ultraje que o culto báquico causou em Roma em 186 AEC, em sua História de Roma, 39.8 [LIVY, JULIUS OBSEQUENS. History of Rome, 39.8. LCL 313]: "Consulibus ambobus quaestio de clandestinis coniurationibus decreta est. Graecus ignobilis in Etruriam primum venit nulla cum arte earum quas multas ad animorum corporumque cultum nobis eruditissima omnium gens invexit, sacrificulus et vates; nec is qui aperta religione, propalam et quaestum et disciplinam profitendo, animos errore imbueret, sed occultorum et nocturnorum antistes sacrorum. Initia erant quae primo paucis tradita sunt, dein volgari coepta sunt per viros mulieresque. additae voluptates religioni vini et epularum, quo plurium animi inlicerentur. Cum vinum animos mosset, et nox et mixti feminis mares, aetatis tenerae maioribus, discrimen omne pudoris exstinxissent, corruptelae primum omnis generis fieri coeptae, cum ad id quisque quo natura pronioris libidinis esset paratam voluptatem haberet. Nec unum genus noxae, stupra promiscua ingenuorum feminarumque erant, sed falsi testes falsa signa testamentaque et indicia ex eadem officina exibant; venena indidem intestinaeque caedes, ita ut ne corpora quidem interdum ad sepulturam exstarent. Multa dolo pleraque per vim audebantur. occulebat vim quod prae ululatibus tympanorumque et cymbalorum strepitu nulla vox quiritantium inter stupra et caedes exaudiri poterat". É de se duvidar - mais ainda por tratar-se de um culto de mistérios - que todos os excessos e o alcance do dionisismo "à romana” tenham de fato sido táo grandes, mas sabemos que em 186 AEC o culto causou furor. Sobre o tema, cf. ainda o livro bastante útil sobre o assunto e temas correlatos de Sutton (1993) e Rouselle (1987, p. 193 ss.). 
Sabemos que Espártaco tinha uma companheira, e que esta provavelmente era de origem trácia, como ele. Não sabemos como ou onde se conheceram. Dificilmente seria na Trácia, pois nesse caso teriam se mantido unidos durante fases muito diferentes da vida de Espártaco, e ao longo de pelo menos sete anos antes da revolta; uma possibilidade realista é a de terem se conhecido em Roma, local onde Espártaco deve ter sido vendido, por motivos que ignoramos. Plutarco nos diz que

[...] quando Plutarco foi trazido a Roma para ser vendido [como escravo], uma serpente foi vista enroscando-se em seu rosto enquanto dormia, e sua esposa [sic], que era da mesma tribo de Espártaco, profetisa, e sujeita a visitas de Dioniso, afirmou que aquilo era a marca de uma força imensa e formidável que garantiria [a Espártaco] algo formidável ${ }^{33}$. Essa mulher vivia com ele e estava junto de [Espártaco] quando de sua fuga ${ }^{34}$.

E, no entanto, ao longo de toda a saga de Espártaco, essa companheira permanece sem nome. Isso não era incomum no mundo greco-romano, mas o fato de ela também ser escrava pode ter agravado o desejo de enterrar sua memória. Essa é a primeira relação que nos é oferecida, cronologicamente, de Espártaco com o dionisismo e a serpente, animal muito importante no culto (KRAEMER, 1979).

Qual o valor desse evento, real ou imaginado, em termos de propaganda? Não sabemos, até por ter ocorrido antes da revolta. Sabemos ainda que o motivo dos gladiadores do ludus de Vatia era - ao menos inicialmente - o modo como eram tratados. A profecia dionisíaca teria inspirado sua ação? Revoltas de gladiadores não eram desconhecidas, e outras ocorreriam depois da de Espártaco. Mas a amplitude da revolta deste deve em grande medida ao papel das mulheres de diversas etnias, o que nos é confirmado por diversas fontes ${ }^{35}$.

Quantas vezes mais a companheira de Espártaco teve êxtases e manipulou serpentes, em consonância com o deus? Não sabemos. Mas dois outros dados devem ser levados em conta aqui: Dioniso era, para vários povos orientais (incluindo os trácios) um deus do êxtase, do vinho e da libertação - todos termos no mesmo campo semântico. No êxtase o sacerdote, profeta, ou sacerdotisa e profetisa fazem coisas não usuais; o vinho torna o comportamento fora de controle acessível a todos. E a libertação política, nesse caso e em costumes que

\footnotetext{
33 Provavelmente no sentido de "um destino notável".

${ }^{34}$ PLUTARCO. Vida de Crasso, 8 [PLUTARCH. Lives, v. III: Pericles and Fabius Maximus. Nicias and

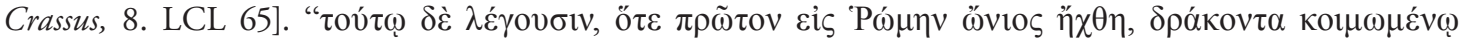

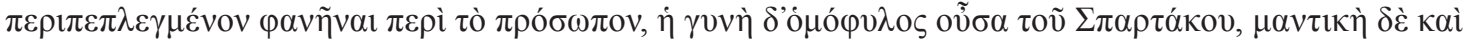

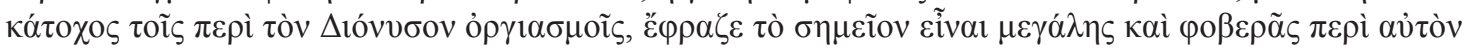

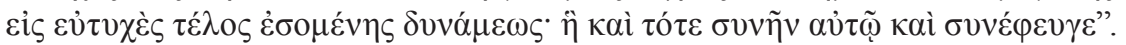

${ }^{35}$ Schiavone (2013, p. 29) sugere que não era improvável que ela seguisse Espártaco durante suas lutas. A informação corresponde ao que sabemos de mulheres de outras etnias, embora em cada grupo étnico esse papel variasse. Outra obra útil nesse sentido, embora muito mais técnica, é o livro de Dupont (1987), especialmente sua "Introduction générale", e, dentro desta, o item 5.1.3. "Lesclave et la révolte" (p. 31).
} 
permaneceram na longa duração ${ }^{36}$, é um traço importante das lutas de trácios contra os romanos (embora com frequência trocassem de lado, e o próprio Espártaco tenha, provavelmente, servido como auxiliar numa unidade romana, como vimos). Mas não era um traço de todos os povos reunidos no melting-pot da revolta: os Getas, por exemplo, tinham no lobo seu animal sagrado. A serpente deve ter sido a mais popular, mas não era unânime em sua popularidade.

O vínculo Dioniso-serpente não é o único possível, mas, ligado à pouca informação que temos sobre a companheira de Espártaco, esclarece alguns pontos. Um deles é que faz sentido supor que o mesmo deus indo-europeu do êxtase tenha sido introduzido mais de uma vez, por assim dizer, no mundo grego: uma pelas civilizaçóes da Era do Bronze, estendendo-se até a Suméria; de outro lado e noutro momento, pelos invasores aqueus e dórios, que, vindo pelo norte da Península Balcânica, imaginaram ser o "seu" deus do êxtase (JEANMAIRE, 1951, p. 77; 430-432) 37 .

Heródoto nos informa que os trácios cultuavam apenas Ares, Dioniso e Ártemis, embora seus reis se reservassem ao culto exclusivo de $\mathrm{Hermes}^{38}$. Mas a informação relativa a outras regiôes próximas é inequívoca: o número de lendas envolvendo a fecundação de Olímpia, mãe de Alexandre, o Grande, são tantas que catalogá-las seria tarefa não para outro artigo, mas para um livro inteiro ${ }^{39}$.

Um dado importante na revolta como um todo é que a profecia da companheira de Espártaco tem sua importância reforçada por diversos pontos, nada desprezíveis. Em primeiro

\footnotetext{
${ }^{36}$ Nos Montes Abruzzos, até os anos 80 do séc. XX, pelo menos, serpentes eram enroscadas na imagem de São Domingos, e, no dia de sua festa, os fiéis seguiam a estátua em procissão. Daniélou (1984, p. 119) parece estar correto ao afirmar que se trata da sobrevivência de um rito dionisíaco.

${ }^{37} \mathrm{O}$ tema do final da Idade do Bronze na Grécia é extremamente complexo e não há aqui espaço suficiente para seu tratamento, nem para suas associaçóes com Dioniso. O leitor interessado em aprofundar o estudo nesses temas pode consultar Palaima (1998, p. 205-222) e Rutherford (2013, p. 256-279). Para um panorama geral do final da Idade do Bronze no Mediterrâneo, uma boa sugestão de leitura é Cline (2014).

${ }^{38}$ HeRÓdOTO. Histórias, 5.7 [HERODOTUS. The Persian Wars, 5.7. LCL 119]. "Oũ̃on $\mu \dot{\varepsilon ̀ v ~ \sigma \varphi \varepsilon ́ \omega v ~ o i ~}$

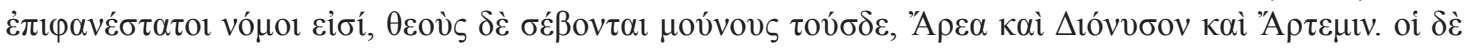

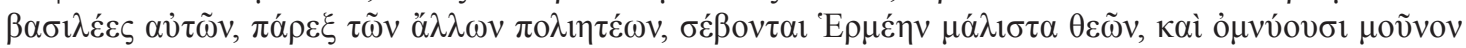

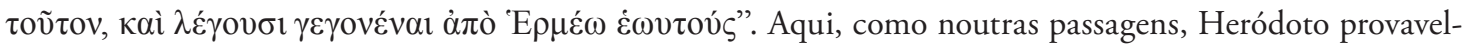
mente está "rebatizando" os deuses locais segundo aqueles que conhece de perto. O uso do vinho em suas festividades pode tê-lo facilmente levado a crer que os trácios veneravam - já no séc. VI ou V AEC - Dioniso. Cf. KOSTADIN (2015, p. 443-445).

${ }^{39}$ PLUTARCO. Os oráculos de Delfos, 401B [PLUTARCH. Moralia, v. V: Isis and Osiris. The E at Delphi. The Oracles at Delphi No Longer Given in Verse, 401B. LCL 306], onde variantes para o nome de Olímpia surgem em conexão com cultos de mistérios (provavelmente, dionisíacos; cf. ainda de Plutarco, Vida de Alexandre, 3 [PLUTARCH. Lives, v. VII: Demosthenes and Cicero. Alexander and Caesar, 3. LCL 99] (quando seu pai, Filipe, vê o leito nupcial sendo divido por uma serpente junto de sua esposa, Olímpia) e ainda com mais ênfase no capítulo 2, onde a mesma aparição teria sido responsável pelo posterior desinteresse de Filipe pela esposa. Cf. Carney (2006, p. 92), o uso e a manipulação de serpentes da Î́ndia até a Itália (com maior frequência na Grécia e regióes ao norte, Macedônia e Trácia) é bem atestado: a serpente é um símbolo do sagrado feminino e por isso mesmo é incomum encontrar manifestaçóes de homens lidando com elas em contexto religioso ou extático.
} 
lugar, para que a presença da cobra fosse ligada ao próprio Espártaco nos diz bastante sobre sua própria religiosidade - talvez uma "camada" a mais no verniz grego de sua formação. Em segundo lugar, a profetisa deve tê-lo acompanhado por dois motivos, não excludentes: escravos eram comprados em lotes e Vatia precisava fazer um mínimo de concessões para que seus gladiadores estivessem motivados. A presença de sua companheira certamente ajudaria nisso.

E, uma vez espalhada a profecia, nos resta o problema de como ela foi aceita de modo tão imediato. Isso não deve surpreender no mundo antigo (aliás, qualquer passeio numa livraria dos dias atuais nos fornece uma amostra de crenças semelhantes); o que realmente chama a atenção do historiador, nesse caso, é a aceitação da profecia por grupos que não necessariamente fossem dionisíacos, ou que tivessem outros animais sagrados. A narrativa da serpente no rosto de Espártaco foi, aparentemente, o combustível ideológico inicial da revolta (materialmente, os maus tratos do ludus bastam como explicação, como visto). Novamente, a conexão Dioniso-universo feminino (domínio da serpente e do submundo) se faz importante.

As versões para a introdução do deus, nas fontes antigas, são inúmeras. Mas talvez a que mais nos auxilie nesse contexto é a do Pseudo-Apolodoro, em sua "Biblioteca" ${ }^{40}$ :

Tendo atravessado a Trácia e toda a Índia e erigido pilares por lá, ele [Dioniso] veio a Tebas, obrigou as mulheres a saírem de suas casas e a entrarem em transe [como Baco - redundância ou interpolação] em Citaeron. Mas Penteu [...] que sucedeu a Cadmo no trono, quis colocar um fim a essas atitudes. Ao chegar ao Monte Citaeron, ao espiar o que as bacantes faziam, foi destroçado, membro por membro, por sua mãe Agave num surto de loucura; pois ela imaginou ser uma fera. Assim, ao mostrar aos tebanos que era um deus, Dioniso chegou a Argos e lá, pelo mesmo motivo, o de não ser honrado, ele enlouqueceu as mulheres, e nas montanhas elas devoraram seus filhos ainda lactantes. Ele quis ser transportado de Icária a Naxos e alugou um barco pirata Tirreno ${ }^{41}$. Mas uma vez a bordo, eles [i.e. os piratas] seguiram por Naxos e foram para a Ásia [Menor], com a intenção de vender [Dioniso] como escravo. Então ele transformou mastro e remos em cobras, encheu o barco de urtigas e o som das flautas. Os piratas enlouqueceram, jogaram-se ao mar e foram transformados em golfinhos ${ }^{42}$.

\footnotetext{
${ }^{40}$ Confundido noutros tempos com Apolodoro de Atenas, que, de todo modo, seria anterior a Espártaco: este viveu entre aproximadamente 180-120 AEC.

${ }^{41}$ Provavelmente de um pirata conhecido por sua ousadia, de nome Heracleo. A relação entre o tráfico de escravos - pirataria e moeda romana encontrada em grande quantidade na atual Romênia (antiga Dácia, região próxima da Trácia e da Macedônia) é bem desenvolvido por Crawford (1977, p. 122). O autor toma o cuidado de não inferir, tout-court, que a presença maciça de denarii na atual Romênia se deva unicamente ao comércio de escravos e suas ligaçóes com a pirataria. Até determinado ponto do desenvolvimento da República, pode-se ver os piratas como quase "sócios" dos romanos pelo volume de escravos que capturavam e vendiam; mas pelo menos após o começo das Guerras Mitradaicas, na década de 80 AEC, essa relação deixa de ser complementar e torna-se abertamente hostil.

${ }^{42}$ PSEUDO-APOLODORO. Biblioteca, 3 [APOLLODORUS. The Library, 3. LCL 121]: “ $\Delta 1 \varepsilon \lambda \theta \dot{\omega} v \delta \delta$

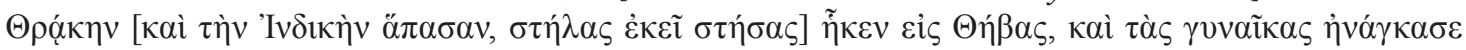

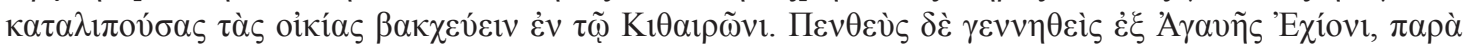


Temos aqui (muito mais do que em Eurípides) praticamente todos os elos causais da narrativa de Espártaco. Teria ele próprio e sua companheira se pautado por essa versáo do mito? Parece mais provável do que um escritor erudito grego modelar sua versão da morte de Penteu a partir da rebelião de um escravo trácio.

Os temas que o Pesudo-Apolodoro elenca são: o êxtase sempre feminino; a duplicidade rei-deus (Penteu contra Dioniso); o comportamento selvagem por parte de quem lhe resiste; e por fim, piratas e, mais do que isso, tirrenos - os mesmos que poderiam ter transportado a massa de Espártaco pelo Estreito de Messina para a Sicília, mas, como os do Pseudo-Apolodoro, trapacearam. Ironicamente, após $52 \mathrm{EC}$, um trácio de nome Sparticus serviu (como seu antecessor) a Roma (não no exército, mas na marinha - nova ironia com relação aos piratas) e recebeu a cidadania romana. Sparticus deve ter servido na unidade naval romana fluvial denominada Classis Pannonica, que patrulhava a área da atual Regensburg até Belgrado.

Todavia, Espártaco não era nenhum deus e, até onde se sabe, nunca pretendeu ter esse tratamento; Dioniso, por sua vez, reintroduz o leitmotif das cobras para vencer os piratas que também estavam a transportá-lo. Quatro itens em comum, portanto - num intervalo de tempo, relativamente a Eurípides, nascido há mais de 400 anos antes da revolta; com relação ao Pseudo-Apolodoro, 170 a 300 anos depois.

Convém lembrar que nossas duas fontes principais para a revolta de Espártaco - a Vida de Crasso, de Plutarco e as Guerras Civis, de Apiano - divergem em vários pontos. Como Plutarco poderia saber do detalhe da companheira e da profecia, quase 200 anos depois? Provavelmente, por alguma seção de Salústio - talvez o mais simpático aos revoltosos entre os historiadores antigos.

\section{Conclusão}

A serpente não era um símbolo exclusivo de Espártaco: nem era o único que contribuía para sua imagem, a julgar pelas descriçôes que temos. Dioniso não é supostamente um deus

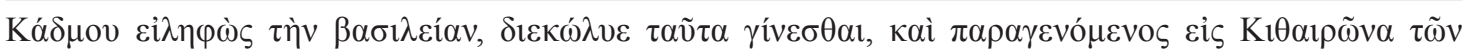

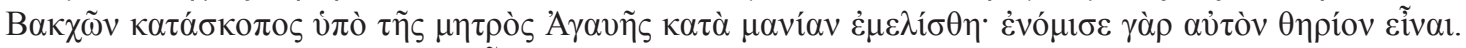

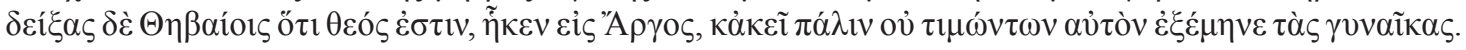

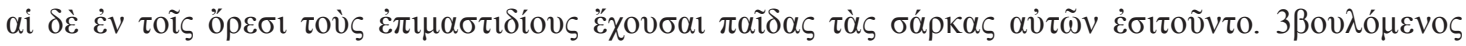

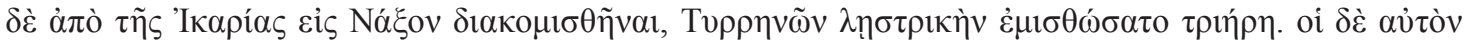

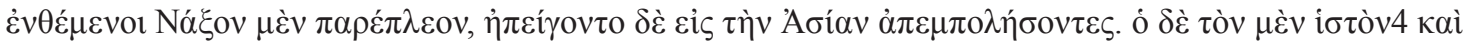

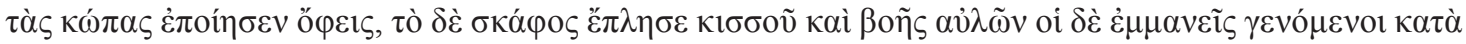

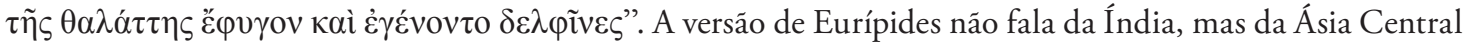
(Báctria) e Irã (As bacantes, 13-18 - [EURIPIDES. Bacchae, 13-18. LCL 495]), embora Eurípides frise em mais de um ponto a natureza mântica do êxtase dionisíaco: "O deus é também um adivinho [mántis como profeta soaria anacrônico, embora comum nas traduçóes da peça]: pois os extáticos e loucos têm poderes de

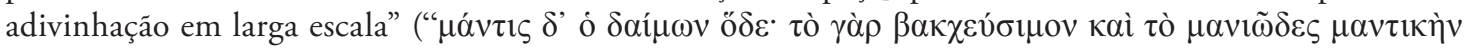
$\pi \mathrm{o} \lambda \lambda \eta े v ~ \varepsilon ้ \chi \varepsilon 1 ; ”)$. Evidentemente, os episódios posteriores a Penteu não fazem parte da peça de Eurípides. Damos ao Pseudo-Apolodoro aqui a dignidade que seus textos merecem, como compilação de mitos antigos. 
libertador: temos outras evidências, e para a mesma regiáo de seu papel na resistência religiosa ou cultural aos romanos. No ano $15 \mathrm{AEC}$ ocorreu (mais uma) revolta trácia contra os romanos: seu líder era um sacerdote de Dioniso, de nome Vologeses ou semelhante, já que é uma latinização ${ }^{43}$. O sincretismo com Sabazius ou Zagreu também é atestado na região: Alexandre Polyhistor informa que dois deuses, "Sol” e "Liber" eram venerados na Trácia sob o mesmo nome, Sabazius (JACOBY, FrGH 273F 103).

Em todo caso, seria errado fazer uma simplificação entre libertação pelo êxtase e ensejo de libertação de fato. Parece mais correto enxergar nas três guerras servis, mas notadamente na que abordamos neste artigo, a terceira, uma variante do velho tema da vitória, vingança ou acerto de contas do Oriente contra o Ocidente ${ }^{44}$. Novamente, deve-se observar que boa parte do contingente de escravos revoltosos era - pelos nossos padróes geográficos - "ocidental". Mas pela orientação geográfica do mundo greco-romano, é mais correto identificá-los como "habitantes nas franjas do mundo civilizado". Entre estes, podemos distinguir duas categorias básicas: aqueles imaginários (que povoavam de bom grado a imaginação dos gregos, como por exemplo os "hiperbóreos" e os "galactófagos" ${ }^{\text {"⿻5 }}$ ) e aqueles de existência concreta, como os trácios, celtas e germanos.

Já enfatizamos o suficiente sua relevância em termos de quantidade. Teriam eles também noção de um "acerto de contas" com Roma ou, antes disso, com o mundo grego, como percebemos nos Oráculos Sibilinos? Isso é talvez impossível de responder e, de todo modo, foge ao escopo deste artigo. Entretanto, o vínculo Espártaco - Dioniso presume alguns elementos desse tema, presentes na literatura apocalíptica, em oráculos de todos os tipos que circulavam até o final da Antiguidade e, deve-se dizer, no próprio cristianismo (que de modo imprudente esquecemos que é, na essência e em seu nascimento, um culto oriental). Do mesmo modo, o culto de Dioniso (como posteriormente o de Ísis, de Hermes e de Mitra) é estranho à "religiáo cívica", mas lhe transcende: está aberto a todos, como os demais cultos listados acima (e, obviamente, do cristianismo); permite um tipo de libertação no êxtase e, talvez acima de tudo isso, reserva às mulheres papel de destaque.

Sabe-se que as mulheres dos povos ditos bárbaros da fronteira reno-danubiana incentivavam seus consortes a lutar mais e melhor de diversas maneiras: genericamente, elas os elogiavam em alto e bom som ou, pelo contrário, matavam elas mesmas os covardes recuan-

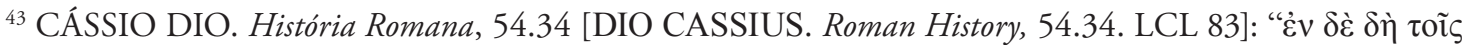

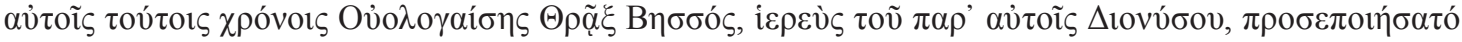
$\tau \imath v \alpha \varsigma \pi \mathrm{o} \lambda \lambda \dot{\alpha} \theta \varepsilon i \alpha ́ \sigma \alpha \varsigma "$.

${ }^{44} \mathrm{O}$ tema vem sendo estudado com frequência cada vez maior nas últimas décadas, possivelmente devido ao influxo teórico da historiografia pós-colonial nas investigaçóes acerca do mundo antigo. De todo modo, as obras seminais no campo são a de Eddy (1961), Fuchs (1938) e o artigo de Kocsis (1962). O artigo de Kippenberg (1983) supracitado contribui de modo mais limitado para a discussão do tema.

${ }^{45}$ Não é tema deste artigo, mas os "galactófagos" já foram "localizados" pelos autores antigos em locais tão díspares quanto a Báctria, a Trácia e a costa norte do Mar Negro; o mesmo com os "hiperbóreos", que podem ter sido apenas trácios ou dácios, mas que outros localizavam na atual Inglaterra.
} 
do (a semelhança com As bacantes não deve ser acidental). Outras participavam do combate mordendo ou arranhando braços e pernas dos romanos. Que isso tenha ocorrido na revolta de Espártaco parece fora de dúvida.

Todavia, Espártaco por si mesmo não seria - ou não foi - capaz de instilar a confiança inicial necessária à revolta. Para isso dependeu de sua companheira anônima - ela, sim, a intermediária entre o sinal visível do deus (a serpente), sua presença junto ou sobre Espártaco e o "destino notável" que ele teria. É mera especulação, mas dado o alcance comprovado de oráculos produzidos em série, como os relatados por Luciano de Samósata ao final do séc. I EC, deve ter sido muito maior a eficácia de profecias "artesanais", por assim dizer, como a realizada pela companheira de Espártaco. O que Luciano tem a nos dizer sobre a circulação de oráculos de todos os tipos, embora escritos numa escala quase industrial pelo falso profeta que é alvo de seu escárnio e investigação, Alexandre de Abnoteichos?

[Estamos falando] de um bandido muito mais selvagem do que Tilloborus ${ }^{46}$, já que o herói de nossa narrativa [Alexandre de Abnoteichos] exercia seu ofício não nas florestas e montanhas, mas nas cidades, e náo infestava apenas a Mísia ${ }^{47}$ e o Monte $\operatorname{Ida}^{48}$, devastando de vez em quando algumas partes mais distantes da Ásia, [mas] ele lotou todo o Império Romano, ouso dizer, com seu banditismo ${ }^{49}$.

E, com essa última reflexão - a de que a relação entre deuses "estranhos" ao mundo da cidade antiga passa, inúmeras vezes, pela mediação feminina (como exemplos, a Sibila, a sacerdotisa de Apolo em Delfos, as bacantes de Eurípides, Olímpia, a irascível mãe de Alexandre e ela mesma devota de cultos extáticos), encerramos este artigo com a ideia de que, sem sua companheira, a serpente no rosto de Espártaco teria sido apenas mais um réptil num mundo ainda em grande parte hostil ao homem. Com sua companheira, estabelece-se um vínculo com um deus do êxtase e da libertação. Espártaco talvez não tivesse ido tão longe (ou talvez sequer teria se mobilizado) sem esses signos do sagrado, da liberdade e do feminino.

\footnotetext{
${ }^{46}$ Pouco se sabe desse bandido rural, que deve ter sido objeto de um texto hoje perdido de Arriano. Mas seria sua comparaçáo com relatos de práticas oraculares (ainda que demonstravelmente espúrias, como Luciano nos conduz em seu livro), mero acidente? Josefo enumera uma quantidade considerável de "bandidos rurais" que podem muito ser vistos como resistentes aos romanos. Tilloborus poderia ter sido, a seu modo, um tipo similar a Espártaco.

${ }^{47}$ Região ao noroeste da Ásia Menor, talvez a Frígia.

${ }^{48}$ Monte tido como sagrado também na costa oeste da Ásia Menor e que figura em diversos autores antigos, começando por Homero (Odisseia, 19.172) [HOMER. Odyssey, 19.172. LCL 105].

${ }^{49}$ Alexandre de Samósata. Alexandre, ou o falso profeta, 2 [LUCIAN. Alexander the False Prophet, 2. LCL

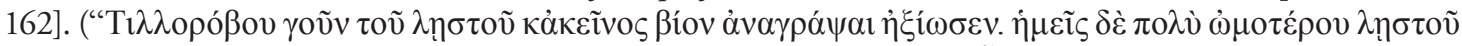

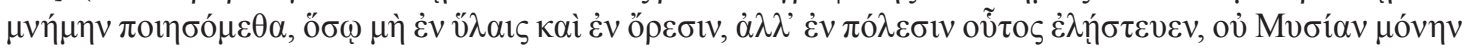

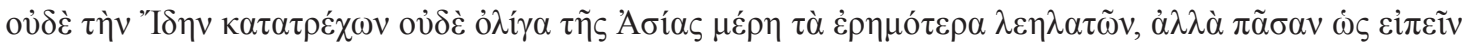

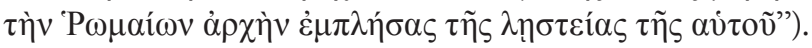




\section{Fontes primárias, ediçóes e traduçóes}

AELIAN. On Animals, Volume III: Books 12-17. Translated by A. F. Scholfield. Loeb Classical Library 449. Cambridge, MA: Harvard University Press, 1959.

APOLLODORUS. The Library, v. I: Books 1-3.9. Translated by James G. Frazer. Loeb Classical Library 121. Cambridge, MA: Harvard University Press, 1921.

APPIAN. Roman History, v. III: The Civil Wars, Books 1-3.26. Translated by Horace White. Loeb Classical Library 4. Cambridge, MA: Harvard University Press, 1913.

ARISTOPHANES. Frogs. Assemblywomen. Wealth. Edited and translated by Jeffrey Henderson. Loeb Classical Library 180. Cambridge, MA: Harvard University Press, 2002. ARRIAN. Anabasis of Alexander, v. II: Books 5-7. Indica. Translated by P. A. Brunt. Loeb Classical Library 269. Cambridge, MA: Harvard University Press, 1983.

CAESAR. Civil War. Edited and translated by Cynthia Damon. Loeb Classical Library 39. Cambridge, MA: Harvard University Press, 2016.

CLAUDIAN. On Stilicho's Consulship 2-3. Panegyric on the Sixth Consulship of Honorius. The Gothic War. Shorter Poems. Rape of Proserpina. Translated by M. Platnauer. Loeb Classical Library 136. Cambridge, MA: Harvard University Press, 1922.

CICERO. Letters to Quintus and Brutus. Letter Fragments. Letter to Octavian. Invectives. Handbook of Electioneering. Edited and translated by D. R. Shackleton Bailey. Loeb Classical Library 462. Cambridge, MA: Harvard University Press, 2002.

DIO CASSIUS. Roman History, v. VI: Books 51-55. Translated by Earnest Cary, Herbert B. Foster. Loeb Classical Library 83. Cambridge, MA: Harvard University Press, 1917.

DIODORUS SICULUS. Library of History, v. XII: Fragments of Books 33-40. Translated by Francis R. Walton. Loeb Classical Library 423. Cambridge, MA: Harvard University Press, 1967.

EURIPIDES. Bacchae. Iphigenia at Aulis. Rhesus. Edited and translated by David Kovacs. Loeb Classical Library 495. Cambridge, MA: Harvard University Press, 2003.

FLORUS. Epitome of Roman History. Translated by E. S. Forster. Loeb Classical Library 231. Cambridge, MA: Harvard University Press, 1929.

FRONTINUS. Stratagems. Aqueducts of Rome. Translated by C. E. Bennett, Mary B. McElwain. Loeb Classical Library 174. Cambridge, MA: Harvard University Press, 1925.

HERODOTUS. The Persian Wars, v. III: Books 5-7. Translated by A. D. Godley. Loeb Classical Library 119. Cambridge, MA: Harvard University Press, 1922.

HERODOTUS. The Persian Wars, v. I: Books 1-2. Translated by A. D. Godley. Loeb Classical Library 117. Cambridge, MA: Harvard University Press, 1920.

HOMER. Odyssey, v. II: Books 13-24. Translated by A. T. Murray. Revised by George E. 
Dimock. Loeb Classical Library 105. Cambridge, MA: Harvard University Press, 1919. JACOBY, Felix. Die Fragmente der griechischen Historiker (FGrHist). Leiden: Brill, 2004. CD-ROM Edition.

LIVY, JULIUS OBSEQUENS. History of Rome, v. XI: Books 38-40. Edited and translated by J. C. Yardley. Loeb Classical Library 313. Cambridge, MA: Harvard University Press, 2018. LIVY, JULIUS OBSEQUENS. History of Rome, v. XIV: Summaries. Fragments. Julius Obsequens. General Index. Translated by Alfred C. Schlesinger. Index by Russel M. Geer. Loeb Classical Library 404. Cambridge, MA: Harvard University Press, 1959.

LUCIAN. Anacharsis or Athletics. Menippus or The Descent into Hades. On Funerals. A Professor of Public Speaking. Alexander the False Prophet. Essays in Portraiture. Essays in Portraiture Defended. The Goddesse of Surrye. Translated by A. M. Harmon. Loeb Classical Library 162. Cambridge, MA: Harvard University Press, 1925.

PHILOSTRATUS. Apollonius of Tyana, v. I: Life of Apollonius of Tyana, Books 1-4. Edited and translated by Christopher P. Jones. Loeb Classical Library 16. Cambridge, MA: Harvard University Press, 2005.

PHOTIUS. The Library of Photius, v. 1. Translated by John Henry Freese. Princeton: University of Princeton, 1920.

PLUTARCH. Lives, v. II: Themistocles and Camillus. Aristides and Cato Major. Cimon and Lucullus. Translated by Bernadotte Perrin. Loeb Classical Library 47. Cambridge, MA: Harvard University Press, 1914.

PlUTARCH. Lives, v. III: Pericles and Fabius Maximus. Nicias and Crassus. Translated by Bernadotte Perrin. Loeb Classical Library 65. Cambridge, MA: Harvard University Press, 1916.

PLUTARCH. Lives, v. VII: Demosthenes and Cicero. Alexander and Caesar. Translated by Bernadotte Perrin. Loeb Classical Library 99. Cambridge, MA: Harvard University Press, 1919.

PLUTARCH. Moralia, v. V: Isis and Osiris. The E at Delphi. The Oracles at Delphi No Longer Given in Verse. The Obsolescence of Oracles. Translated by Frank Cole Babbitt. Loeb Classical Library 306. Cambridge, MA: Harvard University Press, 1936.

QUINTUS CURTIUS. History of Alexander, v. II: Books 6-10. Translated by J. C. Rolfe. Loeb Classical Library 369. Cambridge, MA: Harvard University Press, 1946.

SALLUST. Fragments of the Histories. Letters to Caesar. Edited and translated by John T. Ramsey. Loeb Classical Library 522. Cambridge, MA: Harvard University Press, 2015. SENECA. Epistles, Volume I: Epistles 1-65. Translated by Richard M. Gummere. Loeb Classical Library 75. Cambridge, MA: Harvard University Press, 1917. 


\section{Referências}

ARCHIBALD, Zofia H. Thracian Cult - from Practice to Belief. In: TSETSKHLADZE, Gocha R. (ed.). Ancient Greeks West and East. Leiden / Boston / Köln: Brill, 1999.

ARNAOUTOGLOU, Ilias. Fear of Slaves in Ancient Greek Legal Texts. In: Fear of Slaves - Fear of Enslavement in the Ancient Mediterranean (discourse, representations, practices). Rethymnon 4-7 november 2004. Besançon: Presses Universitaires de Franche-Comté, 2007. p. 133-144.

BRADLEY, Keith R. The Early Development of Slavery at Rome. In: Historical Reflections I Réflexions Historiques, v. 12 [sic], n. 1, 1985. p. 1-8.

BRADLEY, Keith R. Slave Kingdoms and Slave Rebellions in Ancient Sicily. In: Historical Reflections / Réflexions Historiques, v. 10, n. 3, 1993. p. 435-451.

BRADLEY, Keith R. Slavery and Society at Rome. Cambridge / New York / Melbourne: 1994.

CARNEY, Elizabeth. Olympias, Mother of Alexander. New York / London: Routledge, 2006. CLINE, Eric H. 1177 B.C.: The Year Civilization Collapsed. Princeton / Oxford: Princeton University Press, 2014.

CRAWFORD, Michael H. Republican Denarii in Romania: the suppression of piracy and the slave-trade. In: The Journal of Roman Studies, v. 67, 1977. p. 117-124.

DANIÉLOU, Alain. Gods of Love and Ecstasy: the traditions of Shiva and Dionysus. New York: Inner Traditions, 1984.

DETIENNE, Marcel. Dionysus Slain. Baltimore / London: The Johns Hopkins Press, 1979.

DIMITROVA, Nora. Inscriptions and Iconography in the Monuments of the Thracian Rider. In: The Journal of the American School of Classical Studies at Athens, v. 71, n. 2, 2002. p. 209-211.

DUMONT, Jean C. Servus. Rome et l'esclavage sous la République. Roma: École Française de Rome, 1987.

EDDY, Samuel K. The King is Dead. Studies in the Near Eastern Resistance to Hellenism 33431 B. C. Lincoln: University of Nebraska Press, 1961.

FINLEY, Moses I. Ancient Slavery and Modern Ideology. New York: Viking Press, 1980.

FINLEY, Moses I. The Slave Trade in Antiquity: the Black Sea and Danubian regions. In: SHAW, Brent D.; SALLER, Richard (eds). Economy and Society in Ancient Greece [reedição da obra original de Finley com novo prefácio e introdução]. London: Chatto, 1981.

FORREST, William G.; STINTON, Tom C. W.; GREEN, Peter. The First Sicilian Slave War. In: Past \& Present. n. 22, 1962. p. 87-93. 
FUCHS, Harald. Der geistige Widerstand gegen Rom in der antiken Welt. Berlin: Walter de Gruyter, 1938.

GEORGI, Dieter. Forms of Religious Propaganda. In: SCHULTZ, Hans-Jürgen (ed.). Jesus in His Time. Philadelphia: Fortress Press, 1971.

GREEN, Peter. The First Sicilian Slave War. In: Past \& Present, n. 20, 1961. p. 10-29.

HANSON, Victor D. Makers of Ancient Strategy. Princeton: Princeton Universtity Press, 2010.

HARRIS, William V. Towards a Study of the Roman Slave Trade. In: Memoirs of the American Academy in Rome. v. 36 (The Seaborne Commerce of Ancient Rome: Studies in Archaeology and History), 1980. p. 117-140.

HOBBES, Thomas. Leviathan or the Matter, Forme, \& Power of a Commonwealth Ecclesiasticall and Civill. London: printed for Andrew Crooke, at the Green Dragon in St. Pauls Churchyard. 1651 [fac-símile preparado por Rod Hay para a McMaster University Archive of the History of Economic Thought].

HOPKINS, Keith. Conquerors and Slaves: the impact of conquering an empire on the political economy of Italy. In: Conquerors and Slaves. Cambridge: Cambridge University Press, 1978. p. 1-98.

HULTGARD, Anders. Figures messianiques d'Orient comme sauveurs universels dans le monde gréco-romain. In: BIANCHI, Ugo; VERMASEREN, Maarten J. (eds.). La soteriologia dei culti orientali nell'Impero Romano. Atti del Colloquio Internazionale su La soteriologia dei culti orientali nell'Impero Romano. Roma 24-28 settembre 1979. Leiden: Brill, 2015.

JACOBY, Felix. Die Fragmente der griechischen Historiker. Leiden: Brill, 2004 (CD-ROM ed.). JEANMAIRE, Henri. Dionysos, histoire du culte de Bacchus. Paris: Payot, 1951.

KIPPENBERG, Hans G. Dann wird der Orient herrschen und der Okzident dienen. In: BOLZ, Norbert; HUEBENER, Wolfgang (eds.). Spiegel und Gleichnis. Festschrift für Jacob Taubes. Würzburg: Königshausen \& Neumann, 1983.

KLEIN, Günther. Der Synkretismus als Theologisches Problem. In: Rekonstruktion und Interpretation. München: Kaiser Verlag, 1969.

KOCSIS, Elemér. Ost-West Gegensatz in den Jüdischen Sibyllinen. In: Novum Testamentum $5,1962$.

KRAEMER, Ross S. Ecstasy and Possession: the attraction of women to the cult of Dionysus. In: The Harvard Theological Review, v. 72, n. 60, 1979.

MARX, Karl. Karl Marx's 'Confession: Notebook of Jenny Marx (Zalt-Bommel, April $1^{\text {st }}$, 1865). In: MARX, Karl; ENGELS, Frederich. Karl Marx-Frederich Engels: Collected WorksLetters 1864-1868, v. 42. London: Delphi, 2016. p. 567-568. 
MAYOR, Adrienne. The Poison King: the life and legend of Mithridates, Rome's deadliest enemy. Princeton / Oxford: Princeton University Press, 2010.

MOMIGLIANO, Arnaldo. Some Preliminary Remarks on the 'Religious Opposition' to the Roman Empire. In: RAAFLAUB, Kurt A. (ed.). Opposition et résistances à l'Empire d'Auguste à Trajan: neuf exposés suivis de discusssions. Vandœuvres-Genève: Fondation Hardt, 1986. PALAIMA, Thomas. Linear B and the Origins of Greek Religion: 'di-wo-nu-so'. In: DIMOUDIS, Nikolaos; KYRIATSOULIS, Apostolos (eds.). The History of the Hellenic Language and Writings: from the Second to the First Millennium BC: break or continuity. Altenburg: DZA Verlag für Kultur und Wissenschaft, 1998.

PÖHLMANN, Robert von. Geschichter der Sozialen Frage. Antiker Kommunismus und Sozialismus. München: C.H. Beck, 1925 [2 vols.]

ROTH, Ulrike. Men Without Hope. In: Papers of the British School at Rome, v. 79. Cambridge: Cambridge University Press, 2011. p. 71-94.

ROUSELLE, Robert. Liber-Dionysus in Early Roman Drama. In: The Classical Journal, v. 82, n. 3. 1987.

RUBINSOHN, Wofgang Z. Der Spartakus-Aufstand und die sowjetische Geschichsschreibung. Konstanz: Universitätsverlag Konstanz, 1983.

RUTHERFORD, Ian. Mycenaean Religion. In: SALZMAN, Michele R. (org.). The Cambridge History of Religions in the Ancient World, v. 1. Cambridge: Cambridge University Press, 2013.

SANFORD, Eva. Contrasting views of the Roman Empire. In: American Journal of Philology, v. 58, n. 4, p. 437-456, 1937.

SANFORD, Eva. Roman Avarice in Asia. In: Journal of Near Eastern Studies, v. 9, n. 1, p. 28-36, 1950.

SCHIAVONE, Aldo. Spartacus. Cambridge, MA / London: Harvard University Press, 2013. SHAW, Brent D. Spartacus and the Slave Wars. A Brief History with Documents. Boston / New York: Palgrave Macmillan, 2001.PROVA2

STRAUSS, Barry. The Spartacus War. New York: Simon \& Schuster, 2009.

SUTTON, Dana. Ancient Comedy: the War of the Generations. Woodbridge: Twayne Publishers, 1993.

TOYNBEE, Arnold J. The Insurrections of Slaves in the Post-Hannibalic Age. In: Hannibal's Legacy. Oxford: Oxford University Press, 1965.

URBAINCZYK, Theresa. Slave Revolts in Antiquity. London / New York: Routledge, 2008. VALEVA, Julia et al (ed.). A Companion to Ancient Thrace. Malden / Oxford: John Wiley. 2015. 
VERSNEL, Hendrik S. Ter Unus. Isis, Dionysos, Hermes. Three Studies in Henotheism. Leiden New York Kobenhavn Köln: Brill, 1990.

VOGT, Joseph. The Structure of Ancient Slave Wars. In: Ancient Slavery and the Ideal of Man. Oxford: Oxford University Press, 1974. p. 39-92.

WALBANK, Frank W. Prelude to Spartacus: the Romans in Southern Thrace, 150-70 B.C. In: DANOV, Khristo M. et al. Spartacus. Symposium rebus Spartaci gestis dedicatum 2050 a. Sofia: Editions de l'Académie Bulgare des Sciences, 1981. p. 14-27. 